\title{
Articles
}

\section{A Bayesian Spawning Habitat Suitability Model for American Shad in Southeastern United States Rivers}

\author{
Joseph E. Hightower,* Julianne E. Harris, Joshua K. Raabe, Prescott Brownell, C. Ashton Drew
}

\section{J.E. Hightower}

U.S. Geological Survey, North Carolina Cooperative Fish and Wildlife Research Unit, Department of Biology, North Carolina State University, Raleigh, North Carolina 27695

\section{J.E. Harris, J.K. Raabe}

North Carolina Cooperative Fish and Wildlife Research Unit, Department of Biology, North Carolina State University, Raleigh, North Carolina 27695

\section{P. Brownell}

NOAA Fisheries Service, Habitat Conservation Division, Charleston Branch Office, 217 Fort Johnson Road, Charleston, South Carolina 29412

\section{C.A. Drew}

North Carolina Cooperative Fish and Wildlife Research Unit, Biodiversity and Spatial Information Center, Department of Biology, North Carolina State University, Raleigh, North Carolina 27695

\begin{abstract}
Habitat suitability index models for American shad Alosa sapidissima were developed by Stier and Crance in 1985. These models, which were based on a combination of published information and expert opinion, are often used to make decisions about hydropower dam operations and fish passage. The purpose of this study was to develop updated habitat suitability index models for spawning American shad in the southeastern United States, building on the many field and laboratory studies completed since 1985. We surveyed biologists who had knowledge about American shad spawning grounds, assembled a panel of experts to discuss important habitat variables, and used raw data from published and unpublished studies to develop new habitat suitability curves. The updated curves are based on resource selection functions, which can model habitat selectivity based on use and availability of particular habitats. Using field data collected in eight rivers from Virginia to Florida (Mattaponi, Pamunkey, Roanoke, Tar, Neuse, Cape Fear, Pee Dee, St. Johns), we obtained new curves for temperature, current velocity, and depth that were generally similar to the original models. Our new suitability function for substrate was also similar to the original pattern, except that sand (optimal in the original model) has a very low estimated suitability. The Bayesian approach that we used to develop habitat suitability curves provides an objective framework for updating the model as new studies are completed and for testing the model's applicability in other parts of the species' range.
\end{abstract}

Keywords: American; habitat; shad; spawning; suitability

Received: August 19, 2011; Accepted: April 26, 2012; Published Online Early: May 2012; Published: December 2012

Citation: Hightower JE, Harris JE, Raabe JK, Brownell P, Drew CA. 2012. A Bayesian spawning habitat suitability model for American shad in southeastern United States rivers. Journal of Fish and Wildlife Management 3(2):184-198; e1944687X. doi: 10.3996/082011-JFWM-047

Copyright: All material appearing in the Journal of Fish and Wildlife Management is in the public domain and may be reproduced or copied without permission unless specifically noted with the copyright symbol $\odot$. Citation of the source, as given above, is requested.

The findings and conclusions in this article are those of the author(s) and do not necessarily represent the views of the U.S. Fish and Wildlife Service.

* Corresponding author: jhightower@ncsu.edu 


\section{Introduction}

In the early 1970s, the U.S. Fish and Wildlife Service developed a habitat-based methodology for environmental impact assessment and project planning. This included the development of Habitat Suitability Index (HSI) models designed to aid in characterization of species' habitats and assessment of potential development impacts (USFWS 1980; USFWS 1981). Levels for key habitat variables were given scores based on the assumed or estimated suitability for the species, and scores for all variables were typically combined as an estimate of the capacity of an identified area to support the species of interest. These $\mathrm{HSI}$ values range from 0.0 (totally unsuitable habitat) to 1.0 (optimum habitat), and it is assumed that there is a direct linear relationship between the calculated suitability index value and the species' "carrying capacity" in the habitat. For aquatic systems, suitability index curves are also used in Instream Flow Incremental Methodology (IFIM) studies, in which habitat variables are related to stream discharge (Stalnaker et al. 1995). These IFIM methods can be used in comparisons between systems, over time, and between alternative operational plans (e.g., discharge levels in a regulated river) or to predict the potential value of upstream habitat made available through fish passage.

Stier and Crance (1985) developed the first HSI model for American shad Alosa sapidissima (Figure 1). American shad is a historically important anadromous fish that has experienced substantial population declines along the east coast of North America (Limburg et al. 2003). Restoration efforts underway in many large rivers include dam removals and provision of fish passage around dams (Cooke and Leach 2003; Weaver et al. 2003; Burdick and Hightower 2006). Federal Energy Regulatory Commission licensing studies use American shad spawning-habitat suitability curves because of the species' role in deliberations about fish passage and minimum flow regimes. Stier and Crance (1985) developed separate riverine HSI models for spawning and egg-larval stages. Water temperature and current velocity were considered the two most important variables for spawning habitat, while the egg-larval component was based on water temperature. Suitability index curves for IFIM modeling were developed for water temperature, velocity, depth, and substrate. All curves assumed adequate water quality; suitability should be set to zero if dissolved oxygen falls below $5.0 \mathrm{mg} / \mathrm{L}$ for an extended period.

The purpose of this study was to develop data-driven HSI models for spawning American shad in rivers of the southeastern United States (Virginia to Florida). The original Stier and Crance (1985) models were developed using a combination of published information and expert opinion. We used expert opinion to select variables for inclusion, but we based suitability estimates strictly on field data from multiple river systems by using Bayesian statistical methods. This approach provides an objective framework for future updating as additional data become available and for testing and adapting the model for other portions of the species' range.

\section{Methods}

\section{Spawning habitat survey}

We conducted an online survey in November 2008 to gather information about American shad spawning grounds. We sent the survey to agency biologists involved in the 2007 Atlantic States Marine Fisheries Commission stock assessment for American shad (ASMFC 2007) and others actively involved in American shad research or management. Results presented here are for southeastern rivers. Respondents were asked to provide known locations of primary spawning grounds for their local rivers. A location could be the main current spawning grounds or a historically important area currently inaccessible due to dams. Questions included the basis for defining the spawning location (e.g., ichthyoplankton or electrofishing surveys, knowledge of fishing locations, telemetry, or historical accounts) and whether spawning presently occurred in this location due to the presence of an upstream dam.

\section{Expert meeting}

We assembled a group of American shad and habitat experts for a workshop in January 2009 to discuss the important habitat variables for spawning American shad. Invited participants were biologists with recent or ongoing projects on American shad in southeastern systems or those that work directly with habitat suitability models. At the start of the workshop, each expert constructed a flow diagram outlining the most important habitat variables for spawning American shad. The group then discussed key research regarding American shad spawning-habitat suitability, important habitat variables, and raw data available for new analyses.

\section{Habitat suitability curves}

Following the workshop, we developed updated habitat suitability models for water temperature, velocity, depth, and substrate using resource selection functions (RSF). An RSF is any function that describes the relative probability of using resource units with different characteristics, such as spawning sites with different velocities or substrates, (Boyce et al. 2002; Manly et al. 2002). Model parameters are estimated by comparing an organism's use of particular habitats to the landscapewide availability of those habitats (Boyce et al. 2002). For example, if sand and cobble substrates are equally available to an organism but spawning occurs predominately over cobble, such disproportionately higher use indicates a preference for cobble spawning sites. We assume that an organism's spawning-site selection reflects evolved preferences for more suitable habitats. In general, RSFs are entirely data-driven (Boyce et al. 2002) because they do not include expert opinion to assign suitability values; however, expert opinion is used to decide which habitat parameters to include in the model.

We modeled spawning-habitat use with a multinomial distribution, following the approach developed by Thomas et al. (2004). A multinomial distribution is used 


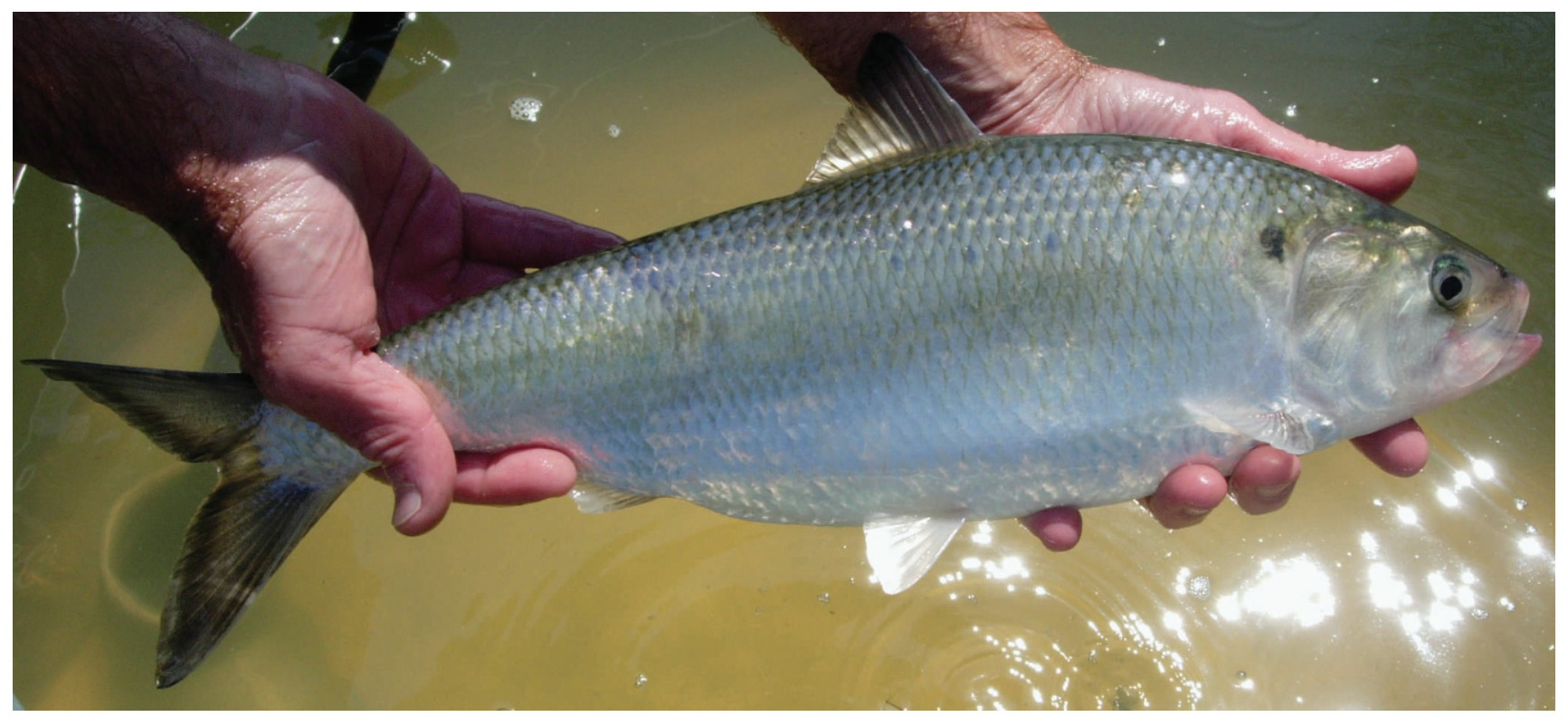

Figure 1. American shad Alosa sapidissima from the Roanoke River at Roanoke Rapids, North Carolina in 2007.

in situations where a trial could result in one of several outcomes, such as the roll of a die or a fish's selection of a site with cobble (instead of silt, sand, etc.) substrate for spawning. The probability $\left(P_{i}\right)$ of using habitat category $i$ is modeled as

$$
P_{i}=\frac{w_{i} a_{i}}{\sum_{j=1}^{h}\left(w_{j} a_{j}\right)}
$$

where $a_{i}$ is the proportion of available habitat in category $i$, and $w_{i}$ is the unscaled relative probability of using habitat $i$ if all habitats were equally available (Thomas et al. 2004). If habitats were used in proportion to their availability, then estimates of the $w_{i}$ would be similar in magnitude (indicating no preference). Thomas et al. (2004) suggest that the $w_{i}$ values be rescaled to sum to 1 , but we rescaled to a maximum of 1 for all habitat variables, so that the scaled $w_{i}$ values can be used as habitat suitability estimates.

We used Bayesian statistical methods to construct RSFs following the approach developed by Thomas et al. (2004). Bayesian methods combine prior information with new data to obtain refined estimates of model parameters (McCarthy 2007). For example, we could have used the suitability index values developed by Stier and Crance (1985) as prior information. Instead, we chose to use uninformative prior distributions to develop new curves based solely on the data. Temperature, current velocity, depth, and substrate type were modeled because they were judged to be important habitat variables (as identified by experts-see below), they could be measured reliably in the field and linked to spawning activity, and data were available from one or more river systems (Table 1). Uncertainty for each suitability curve was characterized using a 95\% Bayesian credible interval $(\mathrm{Cl})$. We estimated the probability of no preference (Bayesian $P$-value) for each habitat variable by comparing the observed data to simulated data sets generated under the null hypothesis of no preference (Thomas et al. 2004). OpenBUGS open-source software (Spiegelhalter et al. 2010) was used in all analyses.

For temperature, current velocity, and depth at spawning, we used the presence or absence of American shad eggs in ichthyoplankton samples as our dependent variable. We used presence or absence rather than egg density because methods differed between studies and American shad abundance likely varied by river system. Samples used to model suitability for temperature were taken over the entire spawning season. This wide temperature range provided contrast in the data set because it included samples from temperatures when spawning did and did not occur. For current velocity and depth, we used studies that collected ichthyoplankton samples over a large extent of the river; thus, samples were completed over the range of velocities and depths available to each population. Although temperature, current velocity, and depth were measured as continuous variables, we aggregated samples into bins in order to use the multinomial model. Available habitat for each variable was estimated by the proportion of samples that were collected at each bin level. We estimated the unscaled relative probabilities $\left(w_{i}\right)$ for each variable (e.g., temperature) using a gamma distribution in order to produce a smoothed pattern across bins. The gamma distribution is a useful function to represent suitability because it provides for smooth (but possibly asymmetrical) changes in suitability as a function of the environmental variable, with low values at the extremes and a maximum at an intermediate value.

We developed the HSI for substrate using data on telemetry and spawning splashes. We considered ichthyoplankton samples less reliable for substrate analyses because eggs are captured downstream of the spawning location. Substrate can be heterogeneously distributed (e.g., small patches), so it is important to have the highest possible spatial precision. In contrast to the other 
Table 1. Studies used to evaluate American shad Alosa sapidissima spawning-habitat selection in southeastern U.S. rivers. For studies with plankton sampling (tows, set nets, and push nets), information on the collection of American shad eggs was used. Tows were oblique or stepped, set nets were anchored for a period of time, and push nets were $1 \mathrm{~m}$ below the surface. For studies that employed telemetry, observations of manually tracked adult American shad or spawning splashes and data on habitat availability were used. "Extent" refers generally to the spatial extent of plankton sampling in the river; "Temp" = water temperature; "Dep" = depth; "Vel" = current velocity; and "Sub" = substrate. Raw data from these studies were either published in a report or obtained by contacting an author.

\begin{tabular}{|c|c|c|c|c|c|c|c|c|c|}
\hline No. & Studies & River & State & Method and/or gear & Extent & Temp & Dep & Vel & Sub \\
\hline 1 & Bilkovic et al. 2002 & $\begin{array}{l}\text { Mattaponi and } \\
\text { Pamunkey }\end{array}$ & VA & $\begin{array}{l}\text { Tows and push nets } \\
\text { (3-7 min) }\end{array}$ & large & $\mathrm{x}$ & $x$ & $\mathrm{x}$ & \\
\hline 2 & Harris and Hightower 2010 & Roanoke & NC & Tows (15 min) & limited & $x$ & & & \\
\hline 3 & Smith 2006 & Tar & NC & Tows (6 min) & large & $x$ & $x$ & & \\
\hline 4 & Burdick and Hightower 2006 & Neuse & NC & Tows (15 min) & large & $x$ & $x$ & $x$ & \\
\hline 5 & Beasley and Hightower 2000 & Neuse & NC & $\begin{array}{l}\text { Sonic telemetry- } \\
\text { spawning splashes }\end{array}$ & & & $x$ & $x$ & $x$ \\
\hline 6 & Bowman 2001 & Neuse & NC & $\begin{array}{l}\text { Radio telemetry- } \\
\text { spawning splashes }\end{array}$ & & & $x$ & $x$ & $x$ \\
\hline 7 & Smith and Hightower 2012 & Cape Fear & NC & Tows (15 min) & moderate & $\mathrm{x}$ & & & \\
\hline 8 & Harris and Hightower $2011 \mathrm{a}^{*}$ & Pee Dee & SC & $\begin{array}{l}\text { Radio telemetry and } \\
\text { tows ( } 15 \mathrm{~min})\end{array}$ & large & $x$ & $x$ & $x$ & $x$ \\
\hline 9 & Williams et al. 1975 & St. Johns & $\mathrm{FL}$ & Set nets (variable h) & large & $x$ & $\mathrm{x}$ & $\mathrm{x}$ & \\
\hline
\end{tabular}

* Habitat availability data for the Pee Dee River were from Fisk (2010).

binned continuous variables, substrate is a categorical variable, so we estimated the unscaled relative probabilities $\left(w_{i}\right)$ separately for each category (Thomas et al. 2004). Available habitat proportions were based on habitat surveys for the Neuse and Pee Dee rivers (Beasley and Hightower 2000; Fisk 2010).

\section{Using the habitat suitability curves}

Habitat suitability scores can be used in a spreadsheet or specialized IFIM software such as PHABSIM (U.S. Geological Survey, Fort Collins, CO). One decision to be made is how to combine suitability values. The PHABSIM software can generate a composite suitability of a cell as either the product, geometric mean, or the minimum of the individual suitabilities (Bovee et al. 1998). For our updated model, we recommend using the geometric mean, which would be zero if any individual index is zero, but would allow for a high score in one index to offset a low score on another one. Note that other variables, such as dissolved oxygen, could be added as suitability functions become available; or the model could be based on fewer variables if appropriate in a particular situation.

We included an example to illustrate the model's use and to compare its ability to predict spawning by American shad to that of the original Stier and Crance (1985) model. We used habitat availability data from the Neuse River collected by Beasley and Hightower (2000) to illustrate the suitability of each site as predicted by our new model and the original Stier and Crance (1985) model. Spatial patterns in predicted suitability from the original and updated models were then compared with independent American shad egg-collection results from ichthyoplankton sampling done by Burdick and Hightower (2006). The predicted suitability of each site sampled for habitat (Beasley and Hightower 2000) was calculated in a spreadsheet (Table S2, Supplemental
Material) using a lookup-table function to assign a suitability for each habitat variable. Water temperatures varied substantially over the $14 \mathrm{~d}$ when habitat data were collected, so we used the geometric mean of suitability values for velocity, depth, and substrate as the composite suitability estimate for each point using the updated model. For comparison, we calculated suitability values for velocity, depth, and substrate from the Stier and Crance (1985) HSI curve for velocity and IFIM curves for depth and substrate. Following the approach used by Stier and Crance (1985) in their HSI model, we calculated the composite index for the original model as the minimum of the three suitability indices.

\section{Results}

\section{Spawning habitat survey}

Survey respondents provided information about primary American shad spawning grounds in 12 southeastern U.S. rivers (Figure 2). Information came from a variety of sources, including historical accounts, ichthyoplankton and electrofishing surveys, telemetry, observations of spawning activity, and angling locations. Spawning grounds in three rivers (St. Johns, Altamaha, Edisto) were located in the Coastal Plain, but most others were near the transition between the Coastal Plain and Piedmont physiographic regions. In three rivers (Savannah, Tar, Roanoke), spawning locations were downstream of dams that were judged to have affected the spawning site location.

\section{Expert meeting}

Participants at the January 2009 meeting of American shad experts determined variables to include in updated American shad spawning-suitability models. Eleven experts constructed flow diagrams of habitat variables 


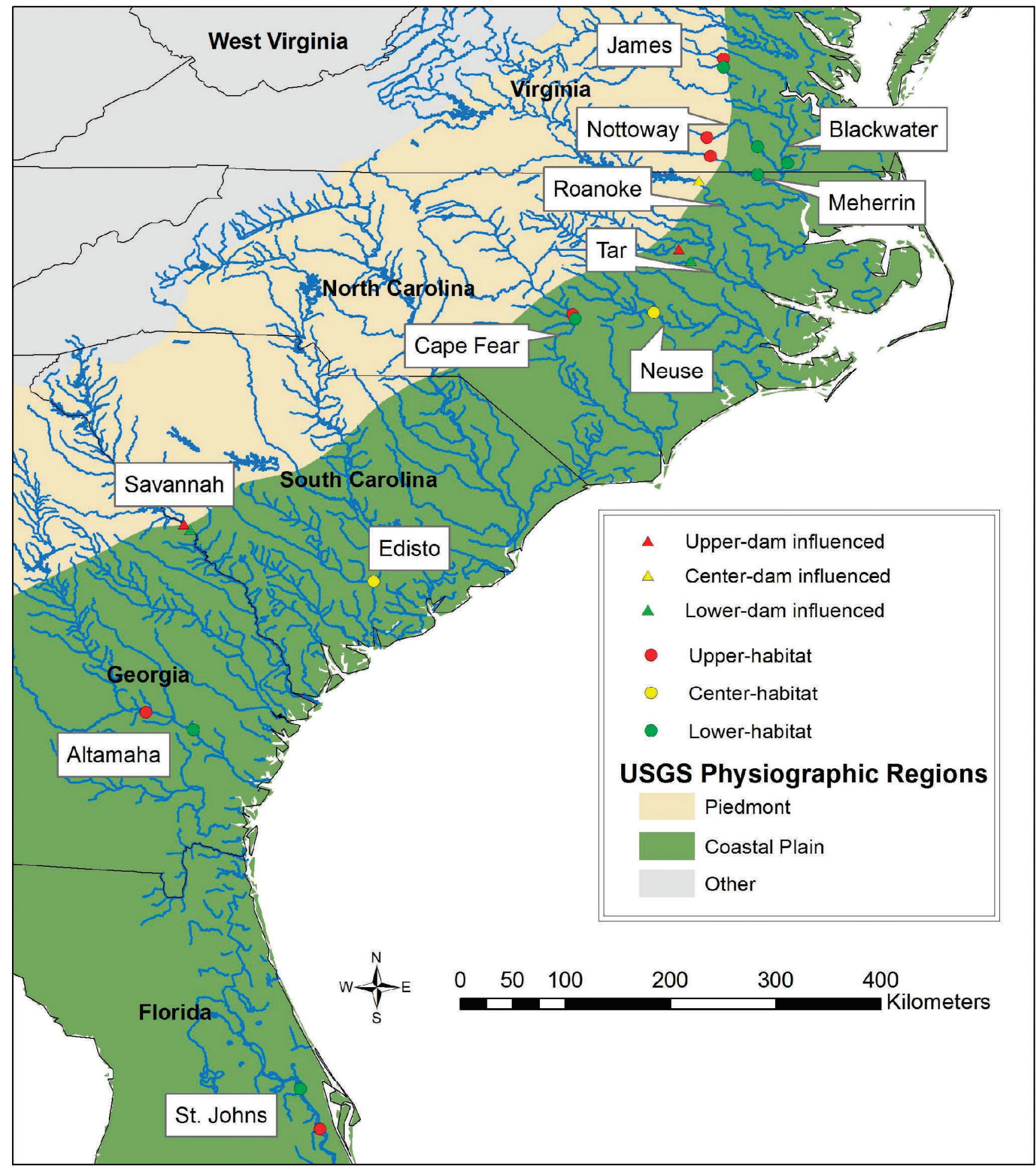

Figure 2. Primary spawning grounds for American shad Alosa sapidissima in southeastern U.S. rivers, based on responses to a November 2008 survey. Respondents were asked to provide latitude and longitude coordinates (center or upper and lower bounds) and to indicate whether the location was judged to be dam-influenced or due to habitat. Map polygons indicate Coastal Plain and Piedmont physiographic regions (U.S. Geological Survey data).

considered important for American shad during spawning and early development stages (Figure 3 ). This exercise occurred at the start of the meeting to capture each individual's knowledge and experience prior to subsequent literature reviews, presentations, and discussions.
Variables at the microhabitat scale were most commonly included in experts' diagrams; in particular, they included water temperature and current velocity (listed by all 11 experts) followed by depth and substrate type (listed by 10 of 11). In addition to current velocity, the dynamics of 


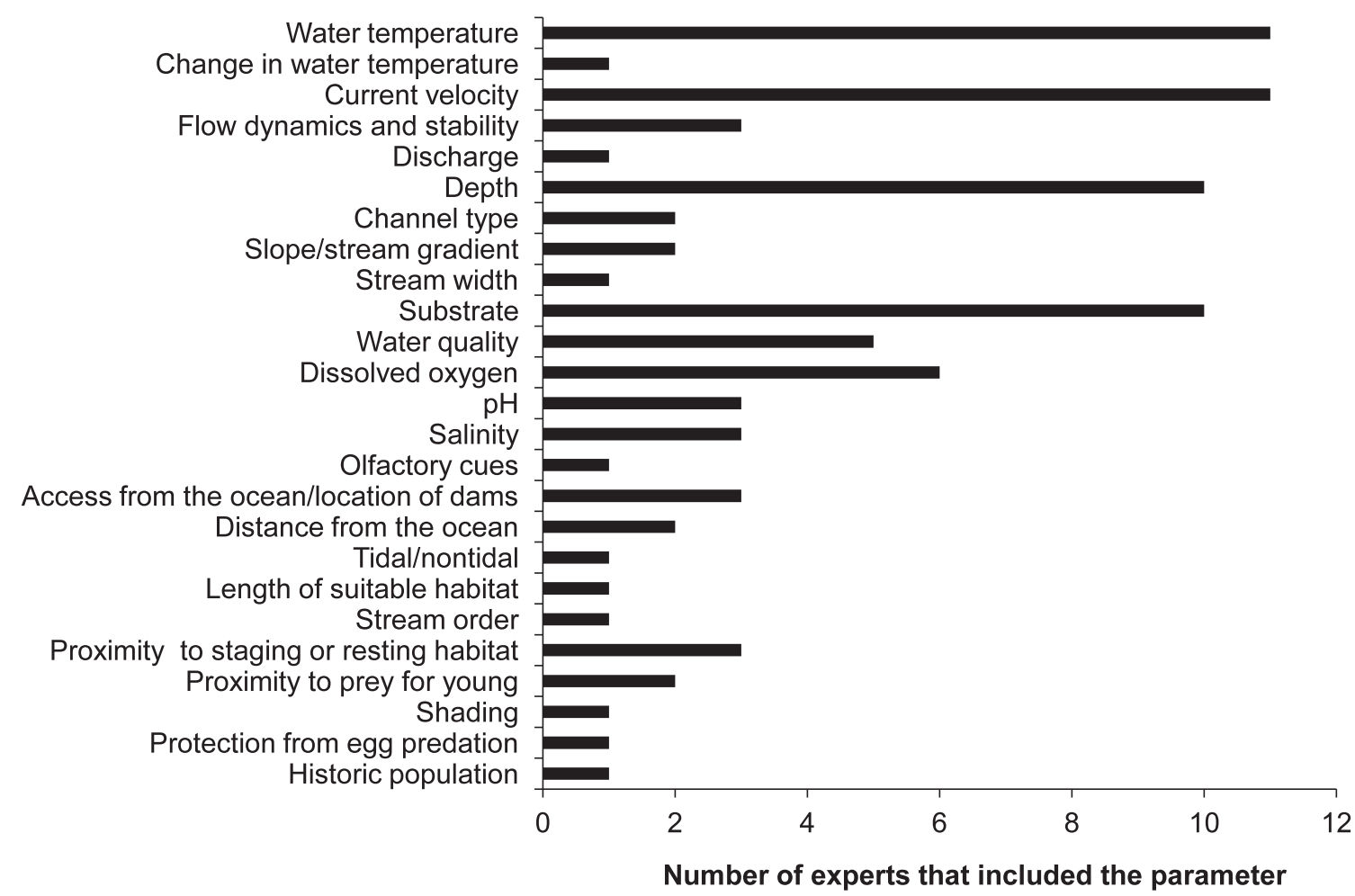

Figure 3. Habitat parameters identified as important for spawning adults and developing young American shad Alosa sapidissima by 11 American shad experts that constructed flow diagrams at the January 2009 American shad habitat-suitability meeting.

flow and flow variability also were identified as important. Numerous comments were made on acceptable spawning substrates, including "sand, gravel," "cobble or other hard substrate," "absence of silt," and "clean substrate," as well as on the correlation between larger substrate particles and higher current velocities. Water quality, including dissolved oxygen (minimum, average) and $\mathrm{pH}$ levels were also identified as important. Overall, experts agreed that certain microhabitat features and high water quality were important components for an updated habitat suitability model for spawning American shad. Macrohabitat features, as well as proximity of spawning habitat to other necessary freshwater habitats, were suggested to be important, but by fewer experts (Figure 3).

Experts also reviewed the available information to update the original Stier and Crance (1985) model. In addition to published field and laboratory studies, raw data were compiled from a variety of studies with sufficiently similar methods such that they could be evaluated together (Table 1). Experts concluded that the microhabitat parameters water temperature, depth, current velocity, and substrate could be evaluated using available field data. Salinity, $\mathrm{pH}$, and dissolved oxygen were considered useful parameters but suitable field data are lacking; laboratory studies are likely the best avenue for estimating suitabilities of these variables.

\section{Habitat suitability curves}

Based on expert opinion and available raw data (Table 1), we updated American shad spawning-habitat suitability curves for water temperature, current velocity, water depth, and substrate. Data used in fitting the curves and estimated suitabilities are provided as Table S1 (Supplemental Material). OpenBUGS code for fitting the models is provided as Text S1 (Supplemental Material).

Temperature. A total of 2,314 ichthyoplankton samples from eight rivers were used to examine habitat suitability for American shad spawning with regard to water temperature. Eggs were collected at temperatures ranging from 6.3 to $27.8^{\circ} \mathrm{C}$. The temperature bin with the highest percentage of positive samples (41\%) was $18^{\circ} \mathrm{C}$ (Figure 4b). The Bayesian multinomial model for temperature produced a scaled resource-selection function with a maximum at $18^{\circ} \mathrm{C}$ (Figure 4a). Estimated suitabilities were relatively precise (narrow $95 \% \mathrm{Cl}$ ). The estimated probability of no habitat preference was $P=0.00$.

Current velocity. A total of 1,113 ichthyoplankton samples were used to examine habitat suitability for American shad spawning with regard to current velocity. Eggs occurred in samples at water velocities ranging from 0.00 to $1.32 \mathrm{~m} / \mathrm{s}$, with the highest percentage of positive samples (all $>40 \%$ ) occurring at water velocities of $\geq 0.6$ $\mathrm{m} / \mathrm{s}$ (Figure $5 \mathrm{~b}$ ). The Bayesian model for water velocity produced a scaled resource-selection function that was relatively flat for $0.6 \mathrm{~m} / \mathrm{s}$ and above, with a maximum at the highest velocity bin (Figure $5 \mathrm{a}$ ). The estimated probability of no habitat preference was $P=5.0 \mathrm{E}-5$.

Depth. American shad eggs were detected in 487 of 1,963 ichthyoplankton samples, at water depths ranging 


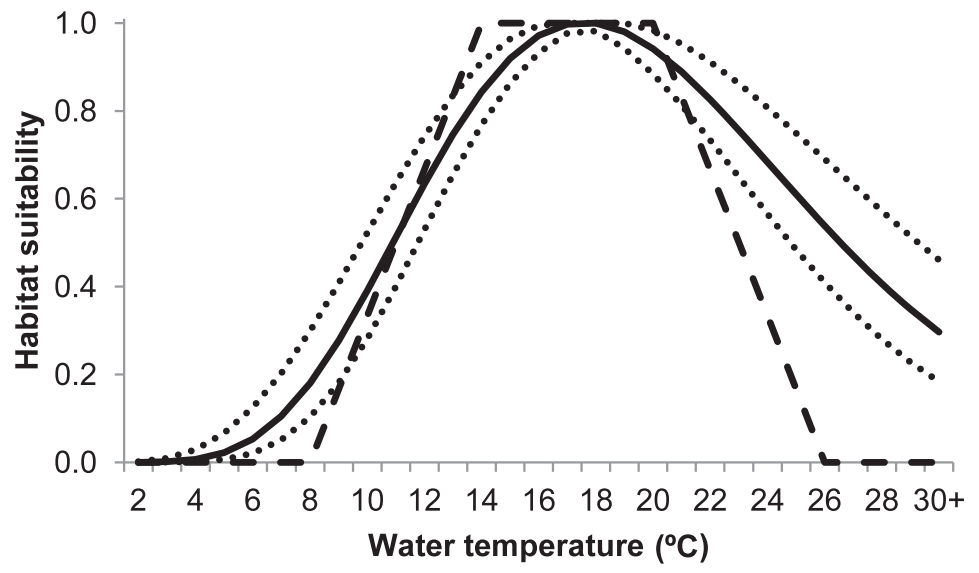

(a)

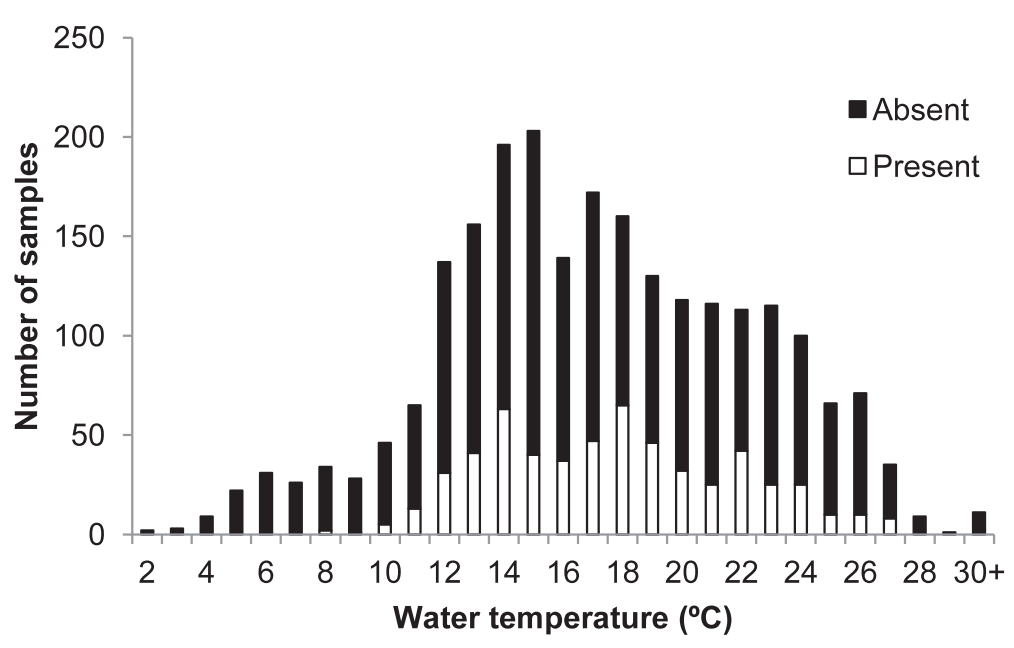

(b)

Figure 4. (a) Estimated American shad Alosa sapidissima spawning-habitat suitability for water temperature (median, with dotted lines indicating $95 \% \mathrm{Cl}$ ) in southeastern U.S. rivers, based on a resource selection function fitted to (b) data on habitat use vs. availability, by temperature. The dashed line shows the suitability curve developed by Stier and Crance (1985).

from 0.5 to $12.0 \mathrm{~m}$. The fraction of samples with eggs was highest (all $>25 \%$ ) for samples collected at $1.5-5 \mathrm{~m}$ (Figure 6b). The Bayesian model for depth produced a scaled resource-selection function with a maximum at $2.5 \mathrm{~m}$ (Figure 6a). The estimated probability of no habitat preference was $P=5.0 \mathrm{E}-5$.

Substrate. Substrate use at spawning sites for American shad was examined with data on 399 spawning splashes in the Neuse River, North Carolina, and 207 relocations of radiotagged adult American shad in the Pee Dee River, North Carolina and South Carolina (Table 1). Substrates were grouped into five categories: silt/clay, sand, gravel, cobble, and boulder/bedrock. Available habitat for the Neuse River was based on 151 samples taken at random locations throughout the Neuse River (Beasley and Hightower 2000). Sand made up a high proportion of available habitat but gravel, cobble, and boulder/bedrock were the most used substrate types for spawning (Figure 7b). Available habitat for the Pee Dee River, based on an IFIM study by Fisk (2010), was quite different from the Neuse River but use vs. availability was similar (Figure 7c). The Bayesian model for substrate produced a scaled resource-selection function that was highest for cobble, followed by gravel and boulder/ bedrock (Figure 7a). The estimated probability of no habitat preference was $P=0.00$.

\section{Using the habitat suitability model}

Predicted spawning-habitat suitabilities for Neuse River sites (Table S1, Supplemental Material) based on velocity, depth, and substrate differed substantially between the original Stier and Crance (1985) and our updated model (Figure 8). Sixty-five of the 103 points had a suitability of $\geq 0.4$ according to the original model, whereas only five points exceeded 0.4 in our updated model. This difference was due primarily to the suitability of sand substrate, which is widespread in the lower Neuse River. Stier and Crance (1985) classified sand as optimal, but it has a very low estimated suitability in the updated model.

\section{Discussion}

Substantial progress has been made in our understanding of American shad biology since the original Stier 


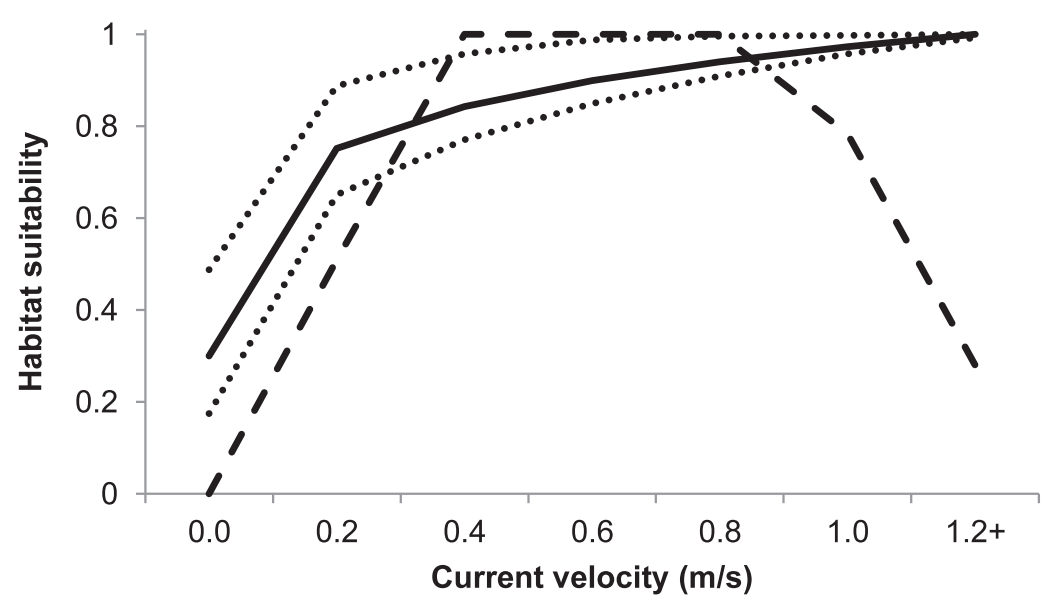

(a)

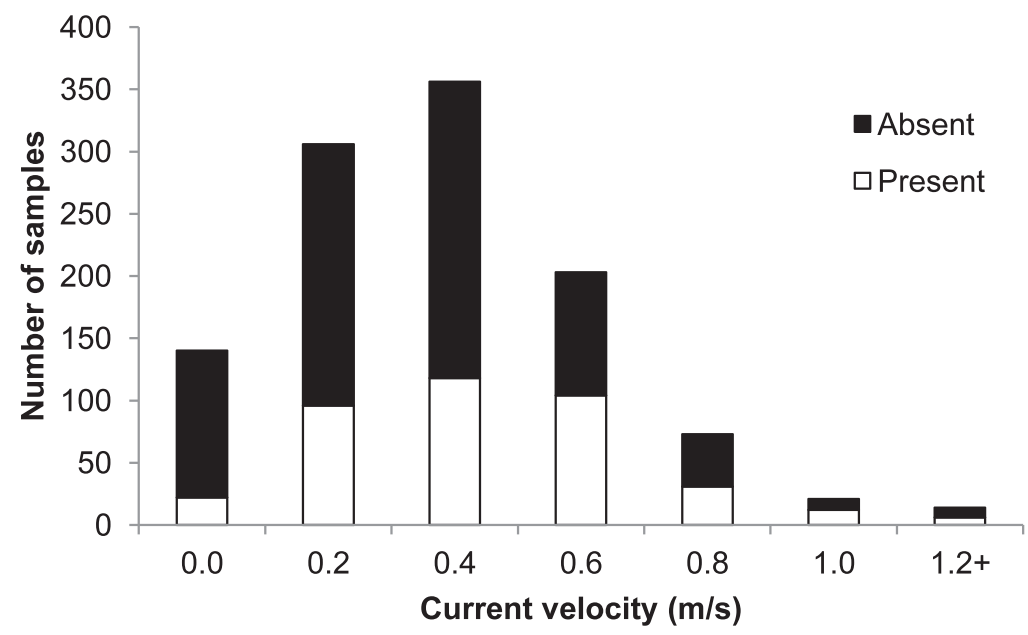

(b)

Figure 5. (a) Estimated American shad Alosa sapidissima spawning-habitat suitability for current velocity (median, with dotted lines indicating $95 \% \mathrm{Cl}$ ) in southeastern U.S. rivers, based on a resource selection function fitted to (b) data on habitat use vs. availability, by $0.2-\mathrm{m} / \mathrm{s}$ velocity bin. The dashed line shows the suitability curve developed by Stier and Crance (1985).

and Crance (1985) report. Field studies in multiple southeastern rivers (Table 1) provide new information about spawning as a function of water temperature, current velocity, depth, and substrate. Our analyses of those new data do not dramatically change the shapes of the habitat suitability curves (except for substrate), but they do provide an objective, data-driven basis for future decision-making. Using an RSF for each variable accounts for sample size and provides an estimate of uncertainty for suitability at all levels of each variable.

Our approach for updating the American shad spawning model should work equally well for other U.S. Fish and Wildlife Service HSI models used in environmental impact assessment and project planning. The most critical aspect will be to locate field data sets that span a broad range of environmental conditions. Sampling is often not done at extreme conditions as a cost savings measure, but those values are important for fitting suitability curves. It is also useful to gather data from multiple rivers in order to characterize geographic variability in habitat preferences. As in this study, we suspect that data collected for other purposes can be used to test and refine many existing models before conducting new field studies.
The updated American shad spawning suitability curves can be tested and further updated as new studies are completed, both within the southeast and in more northern parts of the species' range. Our results could serve as the prior distributions for a Bayesian analysis of new data. If a further updated model is similar to the curves presented here, the new data lend support to our results and increase the precision of suitability estimates. Alternatively, a further updated model producing noticeably different results might indicate differences between river systems and populations of American shad. Such an outcome may warrant a customized local HSI model and likely additional field studies. Although straying does occur, most American shad spawn in their natal rivers (Melvin et al. 1986) and American shad from different rivers have been identified as genetically distinct (Bentzen et al. 1989; Epifanio et al. 1995; Waters et al. 2000; Hasselman et al. 2010). Therefore, the potential exists for populations to become adapted to habitat in their river of origin. For example, Leggett and Carscadden (1978) observed American shad populations exhibiting differences in population dynamics along a latitudinal gradient. A similar latitudinal pattern in genetic differences between populations has not been 

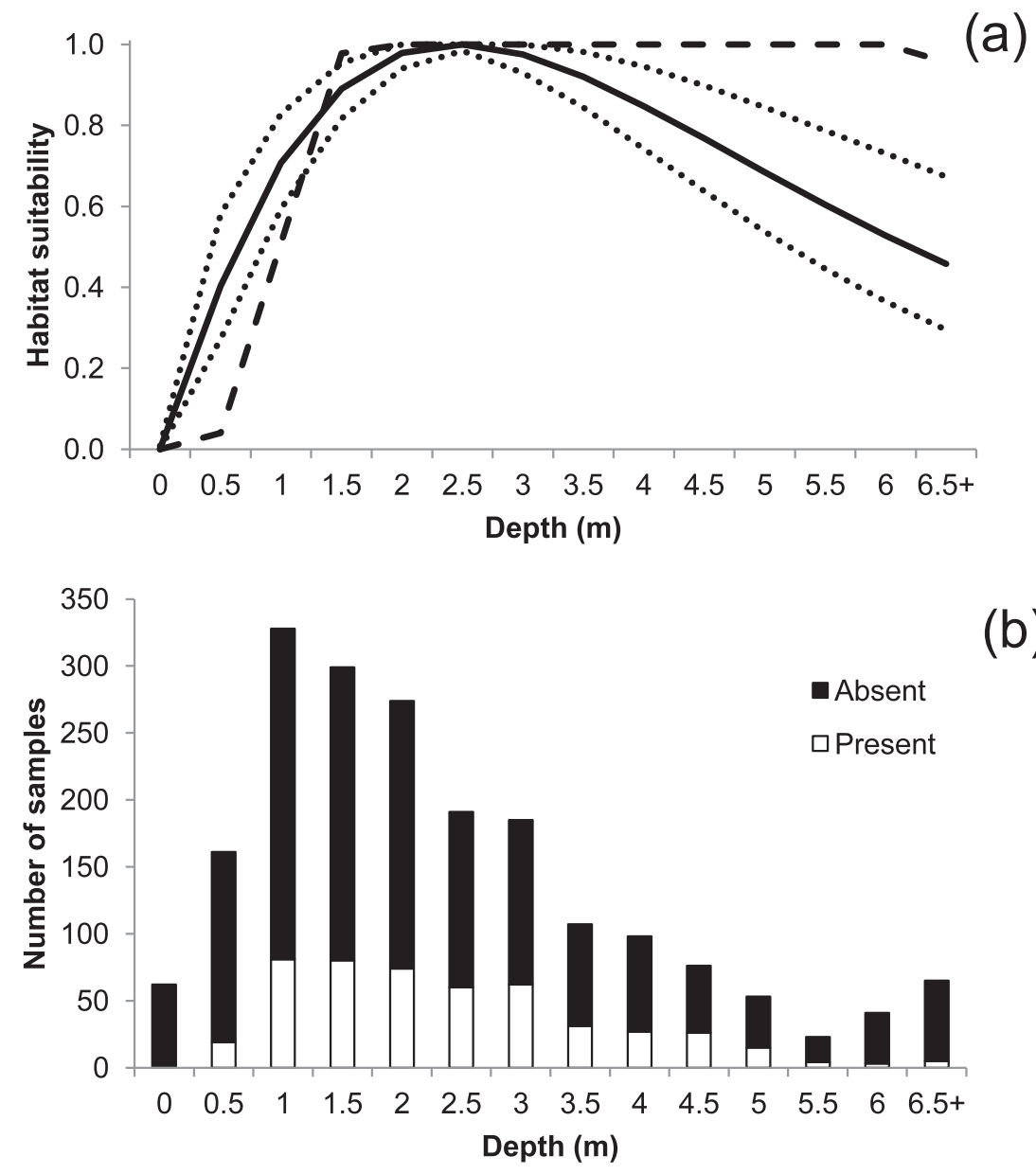

Figure 6. (a) Estimated American shad Alosa sapidissima spawning-habitat suitability for water depth in $\mathrm{m}$ (median, with dotted lines indicating $95 \% \mathrm{Cl}$ ) in southeastern U.S. rivers, based on a resource selection function fitted to (b) data on habitat use vs. availability, by $0.5-\mathrm{m}$ depth bin. The dashed line shows the suitability curve developed by Stier and Crance (1985).

documented (Bentzen et al. 1989; Epifanio et al. 1995; Waters et al. 2000); however, Hasselman et al. (2010) reported a significant increase in genetic differentiation with geographic distance among 12 Canadian populations. To date, no completed studies have suggested differences in spawning habitat selection between populations, but testing this model with new data from other systems could evaluate this potential issue. Additional research on other rivers, in particular northern rivers, would help to examine the model's validity over the species' range.

Our habitat suitability curve for temperature is similar to the original Stier and Crance (1985) curve, but declines more gradually at lower and upper extremes. Leim (1924) reported that American shad eggs developed best at $17^{\circ} \mathrm{C}$, whereas Bradford et al. (1968) indicated that good hatching and development occurred between 15.6 and $26.7^{\circ} \mathrm{C}$. Our updated suitability curve is also similar to the pattern Ross et al. (1993) observed for spawning splashes at different temperatures. They suggested an optimal range of $14-24.5^{\circ} \mathrm{C}$, but were unable to determine an upper limit representing zero suitability. They collected eggs over a temperature range of $8.2-26.6^{\circ} \mathrm{C}$ with a median collection temperature of $19.6^{\circ} \mathrm{C}$.
Our habitat suitability curve for current velocity is relatively flat above $0.4 \mathrm{~m} / \mathrm{s}$, whereas the original Stier and Crance (1985) curve declines sharply at high velocities. Ichthyoplankton data suggest that spawning occurs at all velocity levels, although we recognize that velocity could differ between sites where eggs were collected in plankton samples and sites where spawning occurred. Potentially, eggs are more available for capture in plankton samples in areas with higher velocity because eggs could be retained in the water column instead of settling out in the substrate. Plankton sampling and telemetry results for the Roanoke River indicate that the primary spawning grounds are in a high-gradient $(\sim 1.5 \mathrm{~m} / \mathrm{km})$ section of the river at the physiographic Fall Line, with typical water velocities during the spawning season of $0.2-0.8 \mathrm{~m} / \mathrm{s}$ (Hightower and Sparks 2003). Observed spawning events in the Neuse River occurred at locations with mean velocities of $0.58 \mathrm{~m} / \mathrm{s}$ in 1996-1997 (Beasley and Hightower 2000) and $0.37 \mathrm{~m} / \mathrm{s}$ in 1999-2000 (Bowman 2001). Ross et al. (1993) observed spawning from velocities at or close to zero up to about $0.7 \mathrm{~m} / \mathrm{s}$, and suggested that Stier and Crance's (1985) lower suitability limit was not warranted. Ross et al. (1993) also recommended an upper optimal limit of 


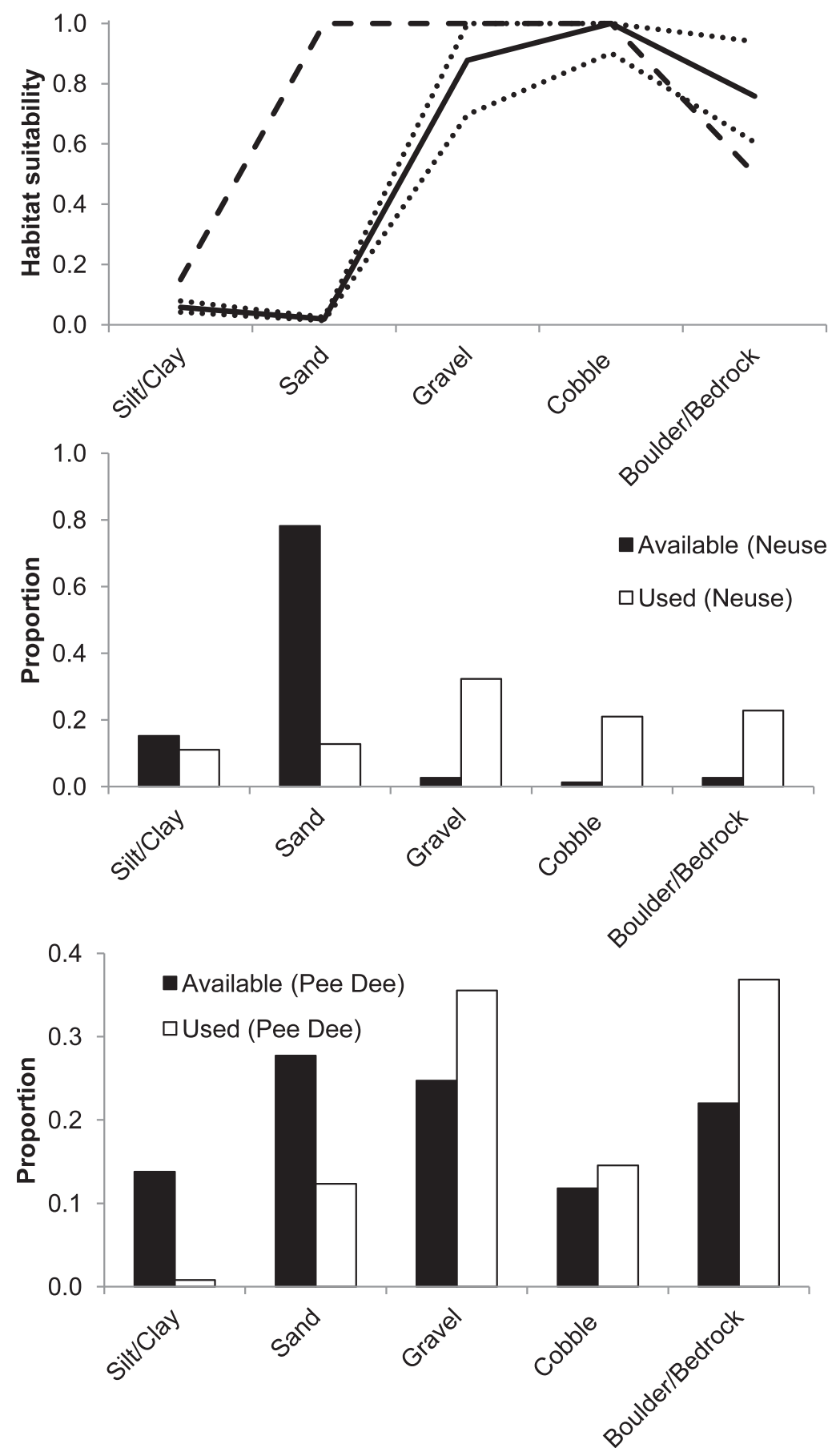

(a)

(b)

(c)

Figure 7. (a) Estimated American shad Alosa sapidissima spawning-habitat suitability for substrate (median, with dotted lines indicating $95 \% \mathrm{Cl}$ ) in southeastern U.S. rivers, based on a resource selection function fitted to (b and $\mathbf{c}$ ) data on habitat use vs. availability, by substrate category. The dashed line shows the suitability curve developed by Stier and Crance (1985), using averages for combined categories (silt/clay, boulder/bedrock).

$0.7 \mathrm{~m} / \mathrm{s}$ rather than the $0.9 \mathrm{~m} / \mathrm{s}$ proposed by Stier and Crance (1985).

Our habitat suitability curve for depth declined more gradually at shallow depths but more quickly in deep water than did the original Stier and Crance (1985) curve. Stier and Crance (1985) proposed an optimal depth range of 1.5-6.1 m, and zero suitability below $0.5 \mathrm{~m}$ and above $15.2 \mathrm{~m}$. In the updated model, suitability exceeds
0.8 over the depth range $1.5-4.0 \mathrm{~m}$, with a maximum at $2.5 \mathrm{~m}$. Bilkovic et al. (2002) suggested that shallow water, high dissolved oxygen, and fast currents may enhance water mixing during American shad spawning, prevent siltation or suffocation of eggs, and transport larvae to productive downstream nursery areas. Observed spawning events in the Neuse River occurred at sites with mean depths of $1.3 \mathrm{~m}$ in 1996-1997 (Beasley and Hightower 


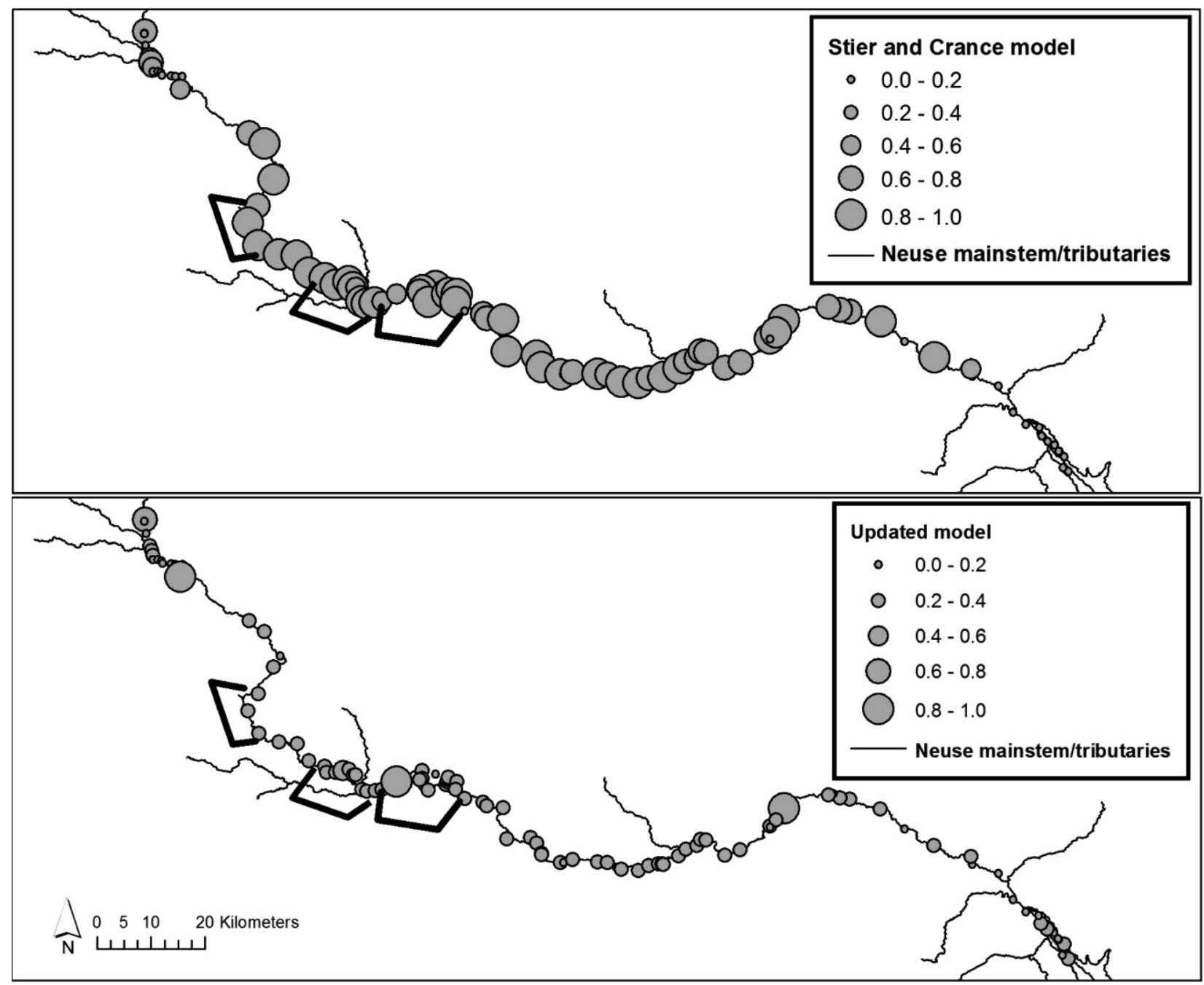

Figure 8. Predicted American shad Alosa sapidissima spawning-habitat suitability for randomly selected Neuse River, North Carolina, sites (Beasley and Hightower 2000), using (a) the original Stier and Crance (1985) model, and (b) our updated model. Lines indicate the three $15-\mathrm{km}$ river reaches that were estimated to have produced the highest relative American shad egg densities in 2003-2004 ichthyoplankton sampling (Burdick and Hightower 2006).

2000) and $1.2 \mathrm{~m}$ in 1999-2000 (Bowman 2001). Similarly, most observed spawning events in the Delaware River were at sites $<2.0 \mathrm{~m}$ in depth (Ross et al. 1993). Observed spawning activity may be a better indicator of depth preference than ichthyoplankton sampling, given that the latter method collects eggs coming from upstream locations (and may not be feasible in very shallow water). However, observed spawning events may also be biased if subsurface spawning is significant. Layzer (1974) reported the collection of eggs at one Connecticut River site where spawning splashes were not observed and suggested that spawning splashes may not be as evident at sites with deep water. Ichthyoplankton sampling data could also be biased toward deeper water sites if eggs in shallow water are more prone to settle out or lodge in the substrate (e.g., Layzer 1974; Moser et al. 1998) and become unavailable for ichthyoplankton sampling.

Our habitat suitability function for substrate was generally similar to the original Stier and Crance (1985) pattern, with sand as the one exception. In the original model, sand was given an optimal suitability score but our analysis resulted in a very low estimated suitability for sand. Sand was highly available within the Neuse River but did not typically occur at sites of observed spawning activity (Beasley and Hightower 2000; Bowman 2001). Results for the Pee Dee River were similar in that radiotelemetered American shad occupied sites with sand substrate less often than expected, based on its availability (Harris and Hightower 2011a). Our RSFs indicated substantially higher suitability values for gravel, cobble, and boulder/bedrock compared with sand and silt/clay. Ross et al. (1993) did not report substrate type at spawning sites but did report that spawning activity was highest in runs and lowest in pools and riffle pools. Runs were defined as a midriver stretch of relatively shallow $(0.5-1.5 \mathrm{~m})$ water of moderate current velocity $(0.3-0.7 \mathrm{~m} / \mathrm{s})$, which is similar to spawning habitat characteristics reported by Beasley and Hightower (2000), Bowman (2001), Bilkovic et al. (2002), and Harris and Hightower (2011a). 
The importance of large substrates has been observed for multiple river-spawning fishes. Riverine areas dominated by larger substrates (such as gravel and cobble) and free from silt are often used as spawning habitat by anadromous alosines (Caswell and Aprahamian 2001; Harris and Hightower 2011b), salmonids (Mull and Wilzbach 2007; Louhi et al. 2011) and sturgeons (Fox et al. 2000; Perrin et al. 2003), as well as freshwater catostomids (Grabowski and Isley 2007; Fisk 2010; Jennings et al. 2010). It has been suggested that eggs deposited on gravel and cobble have higher survival than those deposited on smaller substrates because carbon dioxide and oxygen exchange rates may be higher (Koch et al. 2006; Jennings et al. 2010; Louhi et al. 2011). In addition, appropriately sized gravel and pebble substrates have been shown to provide increased protection from egg predators, as compared with larger or smaller substrates (Palm et al. 2009; Etheridge et al. 2011).

Our updated suitability curves for temperature, velocity, and depth have a single optimal level, compared with the broad optimal ranges for the original Stier and Crance (1985) curves. The curvature results from the comparison of use vs. availability; for example, ichthyoplankton samples often contained eggs at intermediate temperatures but rarely did at the extremes. We modeled these patterns with a gamma function but obtained very similar curves with both a quadratic polynomial and a normal distribution function. Stier and Crance (1985) encouraged the development of this type of "category three" curve based on use vs. availability, compared with "category one" curves based on literature and judgment or "category two" curves based on habitat use only. They note that category three curves theoretically should be transferrable to other systems with different habitats because they remove the effect of habitat availability.

Ichthyoplankton sampling in the Neuse River in 20032004 (Burdick and Hightower 2006) provided some support for our updated model with more narrowly defined optima. Suitability estimates of $\geq 0.4$ were rare for the updated model (5 of 103) but two of those locations were contained within the three $15-\mathrm{km}$ river reaches with highest relative egg densities in the Burdick and Hightower (2006) study (Figure 8). It should be emphasized that two of three field studies used to produce the substrate suitability function and the 20032004 ichthyoplankton samples are from a single river (Neuse), although no information about the spatial pattern was used in developing the curves. Further testing and validation of the entire updated suitability model is warranted, especially the substrate component, which changed considerably from the original Stier and Crance (1985) model.

Methods to identify spawning by American shad (ichthyoplankton sampling, telemetry, and identifying spawning splashes) have different costs and benefits. Ichthyoplankton sampling for American shad eggs is simple, efficient, and highly successful; thus, samples can be completed at many locations in a river over an entire spawning period at relatively low cost (e.g., Burdick and Hightower 2006; see also Harris and Hightower 2010). This efficiency makes it possible to sample over the entire range of conditions (e.g., temperatures below, within, and above the optimal temperature for spawning). The primary disadvantage of ichthyoplankton sampling is that eggs travel an unknown distance between a spawning site and a collection site, as a function of collection method, habitat, and flow (Chittenden 1969; Marcy 1972; Layzer 1974); therefore, the egg collection site may not represent the spawning site. It is possible to estimate the general location (e.g., 5- or $15-\mathrm{km}$ river reaches) of spawning sites using current velocity and egg stage (Burdick and Hightower 2006; Harris and Hightower 2011a), but these estimates do not provide fine-scale information about habitat use. Large rivers are generally well-mixed, so water temperature at the site of egg collection should be a reasonable indicator of temperature at the spawning site (although diel temperature changes could be an issue). This is less likely to be true for current velocity and water depth because eggs may be retained more in the water column in deep areas with high current velocity. Telemetry can evaluate habitat use and movement patterns of adult fish on spawning grounds, but is expensive, laborintensive, and may result in biased information on migration and spawning locations because of effects of handling and tagging (Beasley and Hightower 2000; Hightower and Sparks 2003; Bailey et al. 2004; Olney et al. 2006). Observations of spawning splashes are an excellent way to directly evaluate spawning habitat use if the events are visible and differentiable to species. A disadvantage of using spawning splashes is the possibility that they are more visible in shallow compared with deeper water (Layzer 1974). In addition, observations typically occur at night when American shad spawn (Leim 1924), making it difficult to evaluate spawning intensity over a large portion of a river in a given night. For both telemetry and observations of spawning splashes, an assessment of habitat availability is required, which may be prohibitively labor-intensive if discharge levels change dramatically in the system. Ultimately, including results from multiple methods may be the best strategy for obtaining an unbiased understanding of habitat suitability for American shad.

\section{Supplemental Material}

Please note: The Journal of Fish and Wildlife Management is not responsible for the content or functionality of any supplemental material. Queries should be directed to the corresponding author for the article.

Reference S1. Bovee KD, Lamb BL, Bartholow JM, Stalnaker CB, Taylor J, Henriksen J. 1998. Stream habitat analysis using the instream flow incremental methodology. U.S. Geological Survey, Biological Resources Division Information and Technology Report USGS/BRD-19980004, Fort Collins, Colorado.

Found at DOI: http://dx.doi.org/10.3996/082011JFWM-047.S1 (13601 KB PDF).

Reference S2. Bradford AD, Miller JG, Buss K. 1968. Bioassays on eggs and larval stages of American shad, Alosa sapidissima. Pages 52-60 in Carlson FT. Suitability 
of the Susquehanna River for restoration of shad. U.S. Department of the Interior, Maryland Board of Natural Resources, New York Conservation Department, and the Pennsylvania Fish Commission, Washington, D.C.

Found at DOI: http://dx.doi.org/10.3996/082011JFWM-047.S2 (3115 KB PDF).

Reference S3. Stalnaker C, Lamb BL, Henriksen J, Bovee K, Bartholow J. 1995. The instream flow incremental methodology: a primer for IFIM. U.S. Department of the Interior, National Biological Service, Biological Report 29, Washington, D.C.

Found at DOI: http://dx.doi.org/10.3996/082011JFWM-047.S3 (3782 KB PDF).

Reference S4. Stier DJ, Crance JH. 1985. Habitat suitability index models and instream flow suitability curves: American shad. U.S. Fish and Wildlife Service Biological Report 82(10.88).

Found at DOI: http://dx.doi.org/10.3996/082011JFWM-047.S4 (1062 KB PDF).

Reference S5. [USFWS] U.S. Fish and Wildlife Service. 1980. Habitat as a basis for environmental assessment. 101 ESM. U.S. Department of the Interior, Fish and Wildlife Service, Washington, D.C.

Found at DOI: http://dx.doi.org/10.3996/082011JFWM-047.S5 (1424 KB PDF).

Reference S6. [USFWS] U.S. Fish and Wildlife Service. 1981. Standards for development of habitat suitability models. 103 ESM. U.S. Department of the Interior, Fish and Wildlife Service, Washington, D.C.

Found at DOI: http://dx.doi.org/10.3996/082011JFWM-047.S6 (5497 KB PDF).

Text S1. OpenBUGS code for Bayesian analysis of American shad Alosa sapidissima spawning habitat suitability in southeastern U.S. rivers. Code is provided for (a) water temperature, (b) current velocity, (c) depth, and (d) substrate.

Found at DOI: http://dx.doi.org/10.3996/082011JFWM-047.S7 (21 KB DOCX).

Table S1. Data used in fitting resource selection functions and estimated suitability indices for water temperature, velocity, depth, and substrate.

Found at DOI: http://dx.doi.org/10.3996/082011JFWM-047.S8 (20 KB XLSX).

Table S2. Example of suitability calculations, using habitat characteristics of random Neuse River sites (Beasley and Hightower 2000). Composite scores are based on the geometric mean of suitability estimates for velocity, depth, and substrate. Also calculated for comparison are suitability estimates from the original Stier and Crance (1985) curves for temperature and velocity (HSI curves) as well as depth and substrate (IFIM curves). Composite scores from the Stier and Crance (1985) curves were based on the minimum of the suitability estimates for velocity, depth, and substrate.

Found at DOI: http://dx.doi.org/10.3996/082011JFWM-047.S9 (50 KB XLSX).

\section{Acknowledgments}

We thank the following biologists who responded to the survey about American shad spawning grounds or participated in the Raleigh workshop in January 2009: D. A. Arnold, A. Aunins, D. Bilkovic, M. Brown, M. Cantrell, J. D. Cummings, K. Dockendorf, P. Edwards, J. Ellis, K. A. Hattala, M. L. Hendricks, J. Hoffman, J. W. Kornegay, K. E. Limburg, C. Patterson, W. C. Post, T. F. Savoy, L. M. Miller, F. Rohde, R. A. Sadzinski, M. J. Stangl, S. E. Winslow, and B. Wynne. Matthew Krachey provided valuable advice on Bayesian statistical methods. Fritz Rohde, Joseph Zydlewski, two anonymous reviewers, and the Subject Editor provided helpful comments on previous drafts of this manuscript.

This study was funded by the National Oceanic and Atmospheric Administration. The Cooperative Fish and Wildlife Research Unit is jointly supported by North Carolina State University, North Carolina Wildlife Resources Commission, U.S. Geological Survey, U.S. Fish and Wildlife Service, and Wildlife Management Institute.

Any use of trade, firm, or product names is for descriptive purposes only and does not imply endorsement by the U.S. Government.

\section{References}

[ASMFC] Atlantic States Marine Fisheries Commission. 2007. American shad stock assessment report for peer review. Volume I. Washington, D.C.: Stock Assessment Report 07-01 (Supplement).

Bailey MM, Isely JJ, Bridges WC Jr. 2004. Movement and population size of American shad near a low-head lock and dam. Transactions of the American Fisheries Society 133:300-308.

Beasley CA, Hightower JE. 2000. Effects of a low-head dam on the distribution and characteristics of spawning habitat used by striped bass and American shad. Transactions of the American Fisheries Society 129:1372-1386.

Bentzen P, Brown GC, Leggett WC. 1989. Mitochondrial DNA polymorphism, population structure, and life history variation in American shad (Alosa sapidissima). Canadian Journal of Fisheries and Aquatic Sciences 46: 1446-1454.

Bilkovic DM, Hershner CH, Olney JE. 2002. Macroscale assessment of American shad spawning and nursery habitat in the Mattaponi and Pamunkey rivers, Virginia. North American Journal of Fisheries Management 22:1176-1192.

Bovee KD, Lamb BL, Bartholow JM, Stalnaker CB, Taylor J, Henriksen J. 1998. Stream habitat analysis using the instream flow incremental methodology. Fort Collins, Colorado: U.S. Geological Survey, Biological Resources Division Information and Technology Report USGS/ BRD-1998-0004 (see Supplemental Material, Reference S1, http://dx.doi.org/10.3996/082011-JFWM-047.S1).

Bowman SW. 2001. American shad and striped bass spawning migration and habitat selection in the Neuse River, North Carolina. Master's thesis. Raleigh: 
North Carolina State University. Available: http://www. lib.ncsu.edu/resolver/1840.16/2537 (March 2012).

Boyce MS, Vernier PR, Nielsen SE, Schmiegelow FKA. 2002. Evaluating resource selection functions. Ecological Modelling 157:281-300.

Bradford AD, Miller JG, Buss K. 1968. Bioassays on eggs and larval stages of American shad, Alosa sapidissima. Pages 52-60 in Carlson FT. Suitability of the Susquehanna River for restoration of shad. Washington, D.C.: U.S. Department of the Interior, Maryland Board of Natural Resources, New York Conservation Department, and the Pennsylvania Fish Commission, Washington, D.C. (see Supplemental Material, Reference S2, http://dx.doi.org/10.3996/082011-JFWM-047.S2).

Burdick SM, Hightower JE. 2006. Distribution of spawning activity by anadromous fishes in an Atlantic slope drainage, after the removal of a low-head dam. Transactions of the American Fisheries Society 135:1290-1300.

Caswell PA, Aprahamian MW. 2001. Use of river habitat survey to determine the spawning habitat characteristics of twaite shad (Alosa fallax fallax). Bulletin Francais de la Peche et de la Pisciculture 362/363:919-929.

Chittenden ME. 1969. Life history and ecology of the American shad, Alosa sapidissima, in the Delaware River. Doctoral dissertation. New Brunswick, New Jersey: Rutgers University.

Cooke DW, Leach SD. 2003. Beneficial effects of increased river flow and upstream fish passage on anadromous alosine stocks. Pages 331-338 in Limburg KE, Waldman JR, editors. Biodiversity, status, and conservation of the world's shads. Bethesda, Maryland: American Fisheries Society. Symposium 35.

Epifanio JM, Smouse PE, Kobak CJ, Brown BL. 1995. Mitochondrial DNA divergence among populations of American shad (Alosa sapidissima): how much variation is enough for mixed-stock analysis? Canadian Journal of Fisheries and Aquatic Sciences 52:16881702.

Etheridge EC, Bean CW, Adams CE. 2011. An experimental approach to estimating vulnerability of European whitefish (Coregonus lavaretus) ova to predation by invasive ruffe (Gymnocephalus cernuus). Ecology of Freshwater Fish 20:299-307.

Fisk JM II. 2010. Reproductive ecology and habitat use of the robust redhorse in the Pee Dee River, North Carolina and South Carolina. Master's thesis. Raleigh: North Carolina State University. Available: http://www. lib.ncsu.edu/resolver/1840.16/6416 (March 2012).

Fox DA, Hightower JE, Parauka FM. 2000. Gulf sturgeon spawning migration and habitat in the Choctawhatchee River system, Alabama-Florida. Transactions of the American Fisheries Society 129:811-826.

Grabowski TB, Isley JJ. 2007. Spatial and temporal segregation of spawning habitat by catostomids in the Savannah River, Georgia and South Carolina, U.S.A. Journal of Fish Biology 70:782-798.

Harris JE, Hightower JE. 2010. Evaluation of methods for identifying spawning sites and habitat selection for alosines. North American Journal of Fisheries Management 30:386-399.

Harris JE, Hightower JE. 2011a. Identification of American shad spawning sites and habitat use in the Pee Dee River, North Carolina and South Carolina. North American Journal of Fisheries Management 31:1019-1033.

Harris JE, Hightower JE. 2011b. Spawning habitat selection of hickory shad. North American Journal of Fisheries Management 31:495-505.

Hasselman DJ, Bradford RG, Bentzen P. 2010. Taking stock: defining populations of American shad (Alosa sapidissima) in Canada using neutral genetic markers. Canadian Journal of Fisheries and Aquatic Sciences 67: 1021-1039.

Hightower JE, Sparks KL. 2003. Migration and spawning habitat of American shad in the Roanoke River, North Carolina. Pages 193-199 in Limburg KE, Waldman JR, editors. Biodiversity, status, and conservation of the world's shads. Bethesda, Maryland: American Fisheries Society. Symposium 35.

Jennings CA, Dilts EW, Shelton JL Jr, Cull Peterson R. 2010. Fine sediment effects on survival to emergence of robust redhorse. Environmental Biology of Fishes 87:43-53.

Koch TJ, Congleton JL, Anders PJ. 2006. Effects of sediment cover on survival and development of white sturgeon embryos. North American Journal of Fisheries Management 26:134-141.

Layzer JB. 1974. Spawning sites and behavior of American shad, Alosa sapidissima (Wilson), in the Connecticut River between Holyoke and Turners Falls, Massachusetts, 1972. Master's thesis. Amherst: University of Massachusetts.

Leggett WC, Carscadden JE. 1978. Latitudinal variation in reproductive characteristics of American shad (Alosa sapidissima): evidence for population specific life history strategies in fish. Journal of the Fisheries Research Board of Canada 35:1469-1478.

Leim AH. 1924. The life history of shad, Alosa sapidissima (Wilson), with special reference to the factors limiting its abundance. Contributions to Canadian Biology New Series 2(11):163-284.

Limburg KE, Hattala KA, Kahnle A. 2003. American shad in its native range. Pages 125-140 in Limburg KE, Waldman JR, editors. Biodiversity, status, and conservation of the world's shads. Bethesda, Maryland: American Fisheries Society. Symposium 35.

Louhi P, Ovaska M, Mäki-Petäys A, Erkinaro J, Muotka T. 2011. Does fine sediment constrain salmonid alevin development and survival? Canadian Journal of Fisheries and Aquatic Sciences 68:1819-1826.

Manly BFJ, McDonald LL, Thomas DL, McDonald TL, Erickson PL. 2002. Resource selection by animals: statistical design and analysis for field studies. 2nd edition. Boston: Kluwer Academic Press.

Marcy BC Jr. 1972. Spawning of the American shad, Alosa sapidissima in the lower Connecticut River. Chesapeake Sciences 13(2):116-119. 
McCarthy MA. 2007. Bayesian methods for ecology. New York: Cambridge University Press.

Melvin GD, Dadswell MJ, Martin JD. 1986. Fidelity of American shad, Alosa sapidissima (Clupeidae), to its river of previous spawning. Canadian Journal of Fisheries and Aquatic Sciences 43:640-646.

Moser ML, Bichy JB, Roberts SB. 1998. Sturgeon distribution in North Carolina. Report of the University of North Carolina-Wilmington to U.S. Army Corps of Engineers, Wilmington.

Mull KE, Wilzbach MA. 2007. Selection of spawning sites by coho salmon in a northern California stream. North American Journal of Fisheries Management 27:13431354.

Olney JE, Latour RJ, Watkins BE, Clarke DG. 2006. Migratory behavior of American shad in the York River, Virginia, with implications for estimating in-river exploitation from tag recovery data. Transactions of the American Fisheries Society 135:889-896.

Palm D, Limburg M, Brännäs E, Lundqvist H, Östergren J, Carlsson U. 2009. Influence of European sculpin, Cottus gobio, on Atlantic salmon Salmo salar, recruitment and the effect of gravel size on egg predationimplications for spawning habitat restoration. Fisheries Management and Ecology 16:501-507.

Perrin CJ, Rempel LL, Rosenau ML. 2003. White sturgeon spawning habitat in an unregulated river: Fraser River, Canada. Transactions of the American Fisheries Society 132:154-165.

Ross RM, Bennett RM, Backman TWH. 1993. Habitat use by spawning adult, egg, and larval American shad in the Delaware River. Rivers 4:227-238.

Smith JA, Hightower JE. 2012. Effect of low-head lock and dam structures on migration and spawning of American shad and striped bass in the Cape Fear River, North Carolina. Transactions of the American Fisheries Society 141:402-413.

Smith MC. 2006. Habitat use of early Alosa spp. and striped bass Morone saxatilis in the lower Tar River, North Carolina. Master's thesis. Greenville, North Carolina: East Carolina University.

Spiegelhalter D, Thomas A, Best N, Lunn D. 2010. OpenBUGS user manual, version 3.2.1. Available: http://www. openbugs.info/Manuals/Manual.html (April 2011).
Stalnaker C, Lamb BL, Henriksen J, Bovee K, Bartholow J. 1995. The instream flow incremental methodology: a primer for IFIM. Washington, D.C.: U.S. Department of the Interior, National Biological Service, Biological Report 29 (see Supplemental Material, Reference S3, http://dx.doi.org/10.3996/082011-JFWM-047.S3).

Stier DJ, Crance JH. 1985. Habitat suitability index models and instream flow suitability curves: American shad. U.S. Fish and Wildlife Service Biological Report 82(10.88) (see Supplemental Material, Reference S4, http://dx.doi.org/10.3996/082011-JFWM-047.S4).

Thomas DL, lanuzzi C, Barry RP. 2004. A Bayesian multinomial model for analyzing categorical habitat selection data. Journal of Agricultural, Biological, and Environmental Statistics 9(4):432-442.

[USFWS] U.S. Fish and Wildlife Service. 1980. Habitat as a basis for environmental assessment. 101 ESM. Washington, D.C.: U.S. Department of the Interior, Fish and Wildlife Service (see Supplemental Material, Reference S5, http://dx.doi.org/10.3996/082011-JFWM-047.S5).

[USFWS] U.S. Fish and Wildlife Service. 1981. Standards for development of habitat suitability models. 103 ESM. Washington, D.C.: U.S. Department of the Interior, Fish and Wildlife Service (see Supplemental Material, Reference S6, http://dx.doi.org/10.3996/ 082011-JFWM-047.S6).

Waters JM, Epifanio JM, Gunter T, Brown BL. 2000. Homing behaviour facilitates subtle genetic differentiation among river populations of Alosa sapidissima: microsatellites and mtDNA. Journal of Fish Biology 56: 622-636.

Weaver LA, Fisher MT, Bosher BT, Claud ML, Koth LJ. 2003. Boshers Dam vertical slot fishway: a useful tool to evaluate American shad recovery efforts in the upper James River. Pages 339-347 in Limburg KE, Waldman JR, editors. Biodiversity, status, and conservation of the world's shads. Bethesda, Maryland: American Fisheries Society. Symposium 35.

Williams RO, Grey WF, Huff JA. 1975. Anadromous fish studies in the St. Johns River. Completion report for the 'Study of Anadromous Fishes of Florida' project AFCS-5. Submitted to NOAA, NMFS, St. Petersburg, Florida. Available: http://research.myfwc.com/publications/ publication_info.asp?id=43194 (July 2011). 